\title{
PERBANDINGAN CARA MENCACAH BANYAK LINTASAN TERPENDEK ANTARA DUA TITIK PADA GRID
}

\author{
Wiworo \\ PPPPTK Matematika, Jl. Kaliurang Km.6, Sleman; percussionline@yahoo.com
}

\begin{abstract}
Abstrak. Masalah mencacah banyak lintasan terpendek antara dua titik pada grid merupakan masalah kombinatorika yang sering muncul pada soal kompetisi matematika atau soal pengayaan untuk berbagai jenjang sekolah. Terdapat beberapa cara untuk mencacah, yaitu dengan membuat gambar (representasi visual), pola bilangan pada Segitiga Pascal, dan rumus kombinasi. Tulisan ini membahas perbandingan dari masingmasing cara dikaitkan dengan masalah yang dihadapi. Pada grid sederhana ketiga cara dapat digunakan. Pada grid kompleks hanya rumus kombinasi yang dapat digunakan, kadang-kadang cara pola bilangan pada Segitiga Pascal masih dapat digunakan. Pada grid dengan variasi masalah berupa kendala/hambatan diperlukan kejelian dan fleksibilitas pemilihan cara pencacahan.
\end{abstract}

Kata Kunci. lintasan terpendek, grid, membuat gambar, Segitiga Pascal, kombinasi

\section{A Comparison Of Counting Techniques To Count The Number Of Shortest Paths Between Two Points On A Grid}

\begin{abstract}
The problem of counting the number of shortest paths between two points on a grid is a combinatorial problem that is often found in mathematical competitions or enrichment problems for various levels of school. There are several ways to count, namely by drawing a figure (visual representation), by the number pattern in the Pascal Triangle, and the combination formula. This paper discusses a comparison of each ways related to the problem at hand. On a simple grid all of the three methods can be used. On complex grids the combination formula is the only method can be applied, in some cases the technique of number pattern in Pascal Triangle is still applicable. On the grid with varied obstacles, foresight and flexibility is needed in the selection of the counting methods.
\end{abstract}

Keyword. shortest path, grid, drawing a figure, Pascal Triangle, combination

\section{Pendahuluan}

Kombinatorika merupakan salah satu cabang matematika yang sangat memerlukan kemampuan bernalar, memecahkan masalah, dan komunikasi matematika. Kemampuan komputasi saja tidak banyak membantu dalam memahami materi dan menyelesaikan permasalahan kombinatorika. Khususnya pada masalah mencacah banyak lintasan terpendek antara dua titik pada grid, diperlukan kemampuan dan keterampilan dalam memilih strategi yang tepat untuk dapat memecahkan masalah tersebut. Wiworo (2016) telah menuliskan cara mencacah banyak lintasan terpendek antara dua titik pada grid. Terdapat tiga cara mencacah yang sering digunakan, yaitu dengan cara membuat gambar (representasi visual), menggunakan pola bilangan pada Segitiga Pascal, dan dengan menggunakan rumus kombinasi. Tulisan ini memfokuskan pada perbandingan penggunaan dari masing-masing cara tersebut dikaitkan dengan variasi masalah yang dihadapi. Perbandingan penggunaan dari masing-masing cara ini penting untuk dibahas karena di Indonesia masih minim referensi yang terkait dengan hal tersebut. 


\section{Rumusan Masalah}

Rumusan masalah yang akan dijawab adalah "Bagaimana perbandingan penggunaan dari masing-masing cara mencacah banyak lintasan terpendek antara dua titik pada grid dikaitkan dengan variasi masalah yang dihadapi?"

\section{Dasar Teori}

Pada bagian ini dijelaskan beberapa teori yang digunakan untuk menjawab rumusan masalah, yaitu strategi membuat gambar, koefisien binomial dan hubungannya dengan Segitiga Pascal, Prinsip Bijeksi, dan Teorema Bintang dan Sekat.

Membuat gambar merupakan salah satu strategi dalam memecahkan masalah matematika. Strategi ini tepat digunakan pada situasi ketika masalah yang akan dipecahkan memungkinkan untuk dibuat representasi visualnya dan si pemecah masalah menginginkan untuk memperoleh pemahaman yang lebih baik dari masalah tersebut (Musser, 2014).

Diberikan bilangan bulat $n$ dan $r$ dengan $0 \leq r \leq n$, bilangan $\left(\begin{array}{l}n \\ r\end{array}\right)$ atau $C_{r}^{n}$ didefinisikan sebagai banyaknya himpunan bagian dengan $r$ elemen dari himpunan $\mathbb{N}_{n}=\{1,2, \ldots, n\}$. Dengan kata lain, $\left(\begin{array}{l}n \\ r\end{array}\right)$ adalah banyak cara untuk memilih $r$ objek berbeda dari himpunan $n$ objek berbeda (Meng, 2013). Bilangan $\left(\begin{array}{l}n \\ r\end{array}\right)$ juga dinamakan koefisien binomial (Brualdi, 2010) dan dirumuskan sebagai

$$
\left(\begin{array}{l}
n \\
r
\end{array}\right)=\frac{n !}{r !(n-r) !}
$$

Untuk setiap pasang nilai $n$ dan $r$ yang bersesuaian dapat dituliskan dalam tabel berikut.

Tabel 1. Koefisien binomial untuk setiap pasang $n$ dan $r$

\begin{tabular}{|c|c|c|c|c|c|c|c|c|c|c|}
\hline$r$ & 0 & 1 & 2 & 3 & 4 & 5 & 6 & 7 & 8 & $\cdots$ \\
\hline 0 & 1 & & & & & & & & & \\
\hline 1 & 1 & 1 & & & & & & & & \\
\hline 2 & 1 & 2 & 1 & & & & & & & \\
\hline 3 & 1 & 3 & 3 & 1 & & & & & & \\
\hline 4 & 1 & 4 & 6 & 4 & 1 & & & & & \\
\hline 5 & 1 & 5 & 10 & 10 & 5 & 1 & & & & \\
\hline 6 & 1 & 6 & 15 & 20 & 15 & 6 & 1 & & & \\
\hline 7 & 1 & 7 & 21 & 35 & 35 & 21 & 7 & 1 & & \\
\hline 8 & 1 & 8 & 28 & 56 & 70 & 56 & 28 & 8 & 1 & \\
\hline$\vdots$ & $\vdots$ & $\vdots$ & $\vdots$ & $\vdots$ & $\vdots$ & $\vdots$ & $\vdots$ & $\vdots$ & $\vdots$ & $\ddots$ \\
\hline
\end{tabular}

Dari tabel 1 jelas terlihat bahwa nilai koefisien binomial untuk setiap pasang $n$ dan $r$ membentuk pola bilangan pada Segitiga Pascal. 
Definisi (Patrick, 2007):

Dua himpunan $A$ dan $B$ dikatakan saling berkorespondensi 1-1 jika terdapat suatu fungsi $f$ yang memetakan semua anggota himpunan $A$ ke anggota himpunan $B$ dan memenuhi sifatsifat berikut:

1. Fungsi $f$ adalah injektif, jika $f(x)=f(y)$ maka $x=y$

2. Fungsi $f$ adalah surjektif, untuk setiap $b \in B$ terdapat $a \in A$ sedemikian hingga $f(a)=b$

Fungsi $f$ yang memenuhi kedua sifat tersebut dikatakan sebagai fungsi bijektif.

Korespondensi 1-1 digunakan untuk mengaitkan dua cara berbeda yang merepresentasikan informasi yang sama. Secara umum, pada masalah pencacahan, korespondensi 1-1 digunakan untuk mengganti himpunan yang sulit dicacah dengan himpunan lain yang lebih mudah dicacah (Patrick, 2007).

Prinsip Bijeksi (Chong, 2010):

Misalkan $A$ dan $B$ adalah himpunan berhingga. Jika terdapat fungsi bijektif $f: A \rightarrow B$, maka $n(A)=n(B)$.

Misalkan dipunyai 17 bintang dan 7 sekat. Masalah yang mucul adalah bagaimana menentukan banyak cara menyusun 17 bintang yang tidak dapat dibedakan dan 7 sekat yang tidak dapat dibedakan ke dalam $17+7=24$ slot atau tempat yang ada. Perhatikan dalam masalah penyusunan bintang dan sekat ini, asumsi dasar yang harus digunakan adalah $n$ bintang yang ada tidak dapat dibedakan (indistinguishable), demikian juga $k$ sekat yang ada tidak dapat dibedakan. Beberapa contoh cara penyusunan yang mungkin adalah sebagai berikut.

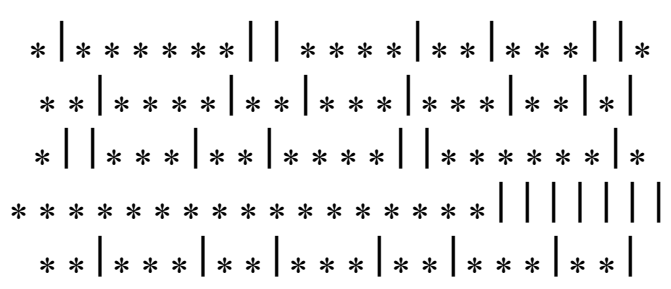

Teorema (Bintang dan Sekat) [Beeleer, 2015]:

Banyak cara menyusun $n$ bintang yang tidak dapat dibedakan dan $k$ sekat yang tidak dapat dibedakan pada slot yang tersedia adalah $\left(\begin{array}{c}n+k \\ k\end{array}\right)$.

Bukti:

Karena akan disusun $n$ bintang dan $k$ sekat, maka terdapat $n+k$ slot yang akan ditempati $n$ bintang dan $k$ sekat tersebut. Dari $n+k$ slot yang tersedia, dipilih $k$ slot untuk menempatkan sekat. Terdapat $\left(\begin{array}{c}n+k \\ k\end{array}\right)$ cara untuk melakukannya. Selanjutnya $n$ bintang ditempatkan pada $n$ slot yang tersisa.

Satu penerapan penting dari Teorema Bintang dan Sekat adalah pada solusi masalah lintasan latis. Titik $(a, b)$ pada bidang koordinat Kartesius dinamakan titik latis (lattice point) jika $a$ 
dan $b$ keduanya merupakan bilangan bulat (Meng, 2013). Gambar berikut ini menunjukkan contoh titik latis $A(1,2), B(3,1)$, dan $C(4,4)$.

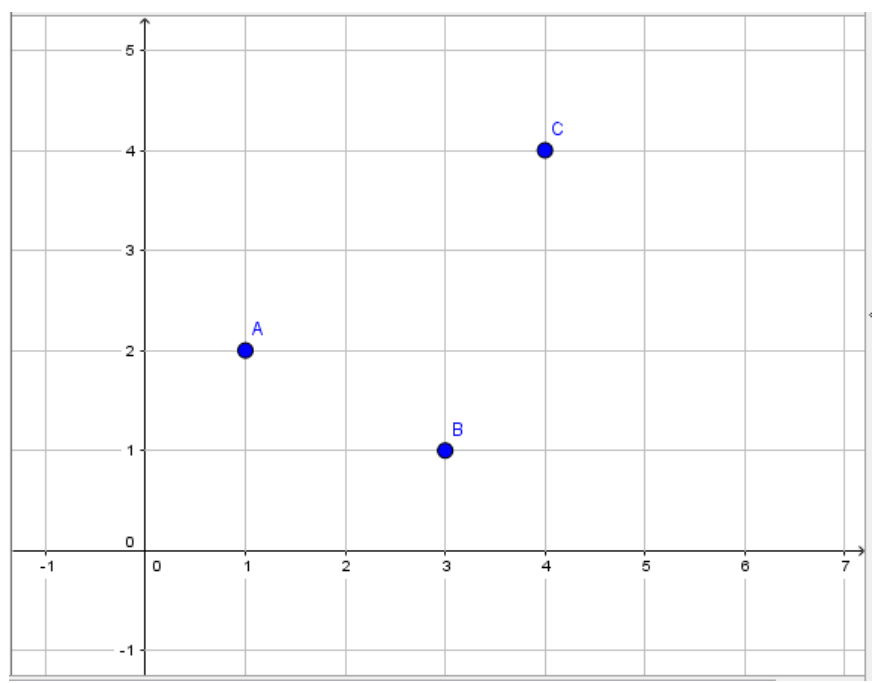

Gambar 1. Contoh titik latis

Lintasan latis (lattice path) dari titik latis $(0,0)$ ke titik latis $(n, k)$ adalah lintasan dengan arah hanya ke kanan dan atas yang melalui titik-titik latis pada bidang koordinat (Beeler, 2015). Gambar berikut menunjukkan contoh tiga lintasan latis dari titik latis $(0,0)$ ke titik latis $(4,4)$.

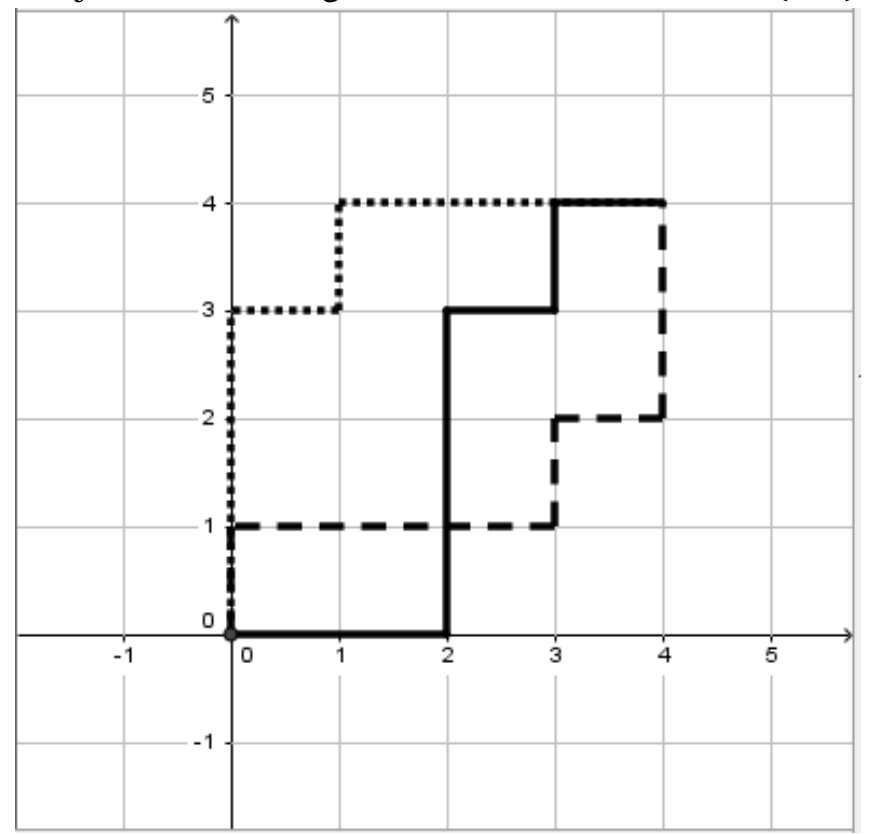

Gambar 2. Contoh lintasan latis

Akibat Teorema Bintang dan Sekat (Beeler, 2015):

Banyak lintasan latis dari $(0,0) \mathrm{ke}(n, k)$ adalah $\left(\begin{array}{c}n+k \\ k\end{array}\right)$. 
Bukti:

Semua langkah pada lintasan latis dari $(0,0)$ ke $(n, k)$ hanya dapat ke kanan $(K)$ dan ke atas (A). Sehingga setiap lintasan ekuivalen dengan penyusunan $n$ huruf $K$ dan $k$ huruf $A$. Dengan demikian, menurut Teorema Bintang dan Sekat, banyak lintasan latis dari $(0,0)$ ke $(n, k)$ adalah $\left(\begin{array}{c}n+k \\ k\end{array}\right)$.

\section{Mencacah Banyak Lintasan Terpendek Pada Grid Sederhana}

Diberikan masalah sebagai berikut. Tentukan banyak lintasan terpendek antara titik $A$ dan titik $B$ pada grid berikut.

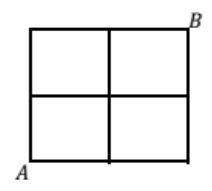

Apabila menggunakan cara membuat gambar (representasi visual), akan terdapat 6 lintasan terpendek dari titik $A$ ke titik $B$, dengan masing-masing lintasan dibuat gambar sebagai berikut.

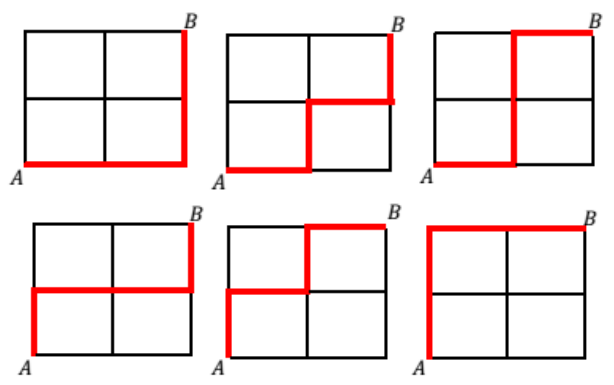

Perhatikan bahwa dengan membuat gambar akan menjadikan langkah solusi dari masalah secara intuitif mudah untuk dipahami.

Apabila menggunakan pola bilangan pada Segitiga Pascal, mula-mula grid disederhanakan menjadi seperti berikut.

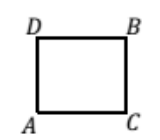

Perhatikan bahwa dari titik $A$ untuk menuju titik $C$ terdapat 1 jalan, dari titik $A$ menuju titik $D$ juga terdapat 1 jalan. Sehingga dari titik $A$ menuju titik $B$ melalui $C$ dan $D$ akan terdapat 2 jalan ( 2 jalan diperoleh dari 1 jalan melalui $C$ ditambah 1 jalan melalui $D$ ). Dengan demikian total terdapat 2 lintasan terpendek dari titik $A$ ke titik $B$.

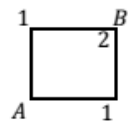

Berikutnya grid dikembangkan menjadi seperti berikut.

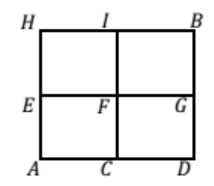

Perhatikan bahwa dari pola grid sebelumnya sudah diketahui terdapat 2 jalan dari titik $A$ menuju titik $F$. Selanjutnya untuk menuju titik $G$ dari titik $D$ dan $F$ masing-masing terdapat 1 jalan. Karena dari titik $A$ ke $F$ terdapat 2 jalan, maka dari $A$ ke $G$ akan terdapat 3 jalan (3 jalan 
diperoleh dari 2 jalan dari $A$ ke $G$ melalui $F$ ditambah 1 jalan dari $A$ ke $G$ melalui $D$ ). Secara analog dari titik $A$ menuju titik $I$ juga terdapat 3 jalan. Banyak lintasan terpendek selengkapnya adalah sebagai berikut.

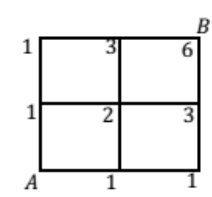

Dari titik $A$ menuju titik $B$ akan terdapat 6 lintasan terpendek (6 jalan diperoleh dari 3 jalan dari $A$ ke $B$ melalui $G$ ditambah 3 jalan dari $A$ ke $B$ melalui $I$ ). Perhatikan bahwa bilanganbilangan yang bersesuaian dengan banyak jalan dari $A$ ke masing-masing titik sampai ke titik $B$ ternyata membentuk pola bilangan pada Segitiga Pascal.

Apabila menggunakan cara kombinasi adalah seperti berikut. Misalkan satu langkah ke kanan dilambangkan sebagai $K$ dan satu langkah ke atas dilambangkan sebagai $A$. Beberapa lintasan terpendek yang mungkin dari titik $A$ ke titik $B$ adalah $K K A A, K A K A, K A A K, A K K A, A K A K$, dan $A A K K$. Perhatikan pada grid tersebut bahwa contoh-contoh lintasan terpendek dari titik $A$ ke titik $B$ ternyata identik dengan masalah banyak cara menyusun beberapa huruf $K$ dan beberapa huruf $A$ pada beberapa slot yang tersedia. Keenam contoh lintasan terpendek dari titik $A$ ke titik $B$ tersebut identik dengan masalah banyak cara menyusun 2 huruf $K$ dan 2 huruf $A$ pada 4 slot yang tersedia. Sehingga banyak lintasan terpendek dari $A$ ke $B$ adalah

$$
\left(\begin{array}{c}
2+2 \\
2
\end{array}\right)=\frac{4 !}{2 ! \cdot 2 !}=6
$$

Terdapat 6 lintasan terpendek dari titik $A$ ke titik $B$. Hasilnya tepat sama dengan apabila menggunakan cara memeragakan atau pola bilangan Segitiga Pascal.

Kesimpulan untuk grid sederhana, ketiga cara dapat digunakan.

\section{Mencacah Banyak Lintasan Terpendek Pada Grid Kompleks}

Diberikan masalah sebagai berikut. Tentukan banyak lintasan terpendek antara titik $A$ dan titik $B$ pada grid berikut.

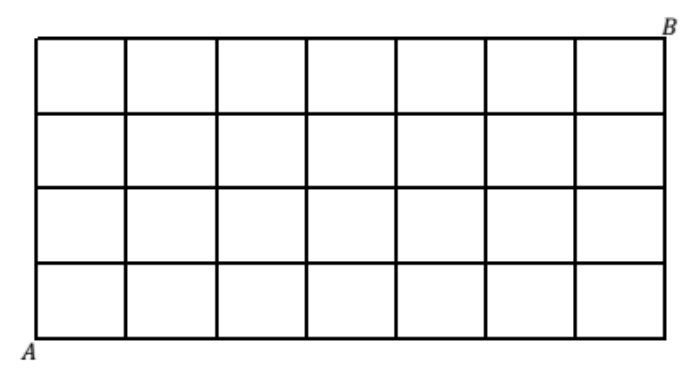

Pada grid kompleks ini penggunaan cara membuat gambar jelas sudah tidak efektif dan efisien. 
Apabila menggunakan pola bilangan pada Segitiga Pascal adalah sebagai berikut.

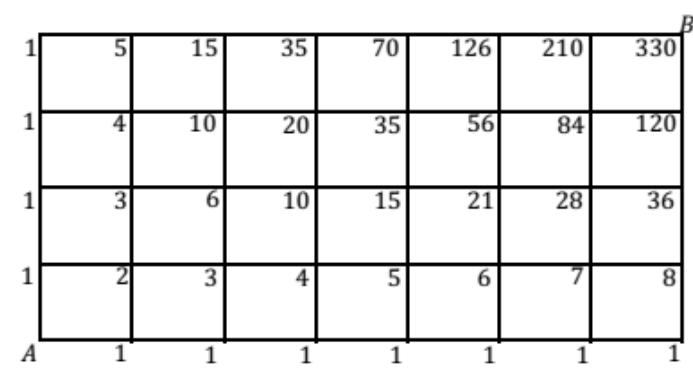

Dengan demikian terdapat 330 lintasan terpendek dari titik $A$ menuju titik $B$.

Apabila menggunakan cara kombinasi adalah sebagai berikut. Beberapa lintasan terpendek yang mungkin dari titik $A$ ke titik $B$ adalah KKKKKKKAAAA, KKAKKAKKAKA, KAKAKKKAKAK, AAAAKKKKKKK, AKKAKKAKKKA, dan AKKKAAKKKKA. Keenam contoh lintasan terpendek dari titik $A$ ke titik $B$ tersebut identik dengan masalah banyak cara menyusun 7 huruf $K$ dan 4 huruf $A$ pada 11 slot yang tersedia. Banyak lintasan terpendek dari $A$ ke $B$ adalah

$$
\left(\begin{array}{c}
7+4 \\
4
\end{array}\right)=\frac{11 !}{7 ! \cdot 4 !}=330
$$

Terdapat 330 lintasan terpendek dari titik $A$ ke titik $B$. Hasilnya tepat sama dengan apabila menggunakan pola bilangan Segitiga Pascal.

Akan ditunjukkan bahwa 11 langkah dari titik $A$ ke titik $B$ pada grid tersebut saling berkorespondensi 1-1 dengan cara menyusun 7 huruf $K$ dan 4 huruf $A$ pada 11 slot yang tersedia. Untuk melakukan 11 langkah dari $A$ ke $B$, kita harus melakukan 7 langkah ke kanan dan 4 langkah ke atas. Setiap penyusunan yang berbeda dari 11 langkah tersebut akan menyebabkan lintasan yang berbeda dari $A$ ke $B$. Jika diberikan satu lintasan, kita dapat menuliskannya sebagai barisan 11 langkah $K$ dan $A$, dengan $K$ menyatakan langkah ke kanan dan $A$ menyatakan langkah ke atas. Sebagai contoh, lintasan berikut ini berkorespondensi dengan penyusunan huruf $K A A K K K A K K A K$.

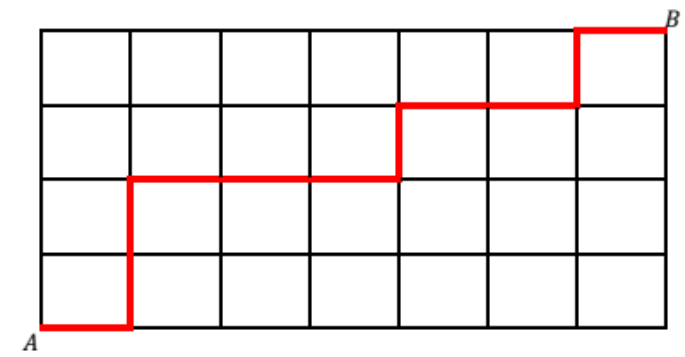

Konversnya, setiap barisan 7 huruf $K$ dan 4 huruf $A$ akan berkorespondensi dengan satu lintasan tunggal yang terdiri dari 7 langkah ke kanan dan 4 langkah ke atas. Dengan demikian dikatakan bahwa dua himpunan tersebut (himpunan lintasan dan himpunan barisan huruf) saling berkorespondensi 1-1.

Apabila diberikan masalah yang lebih kompleks lagi seperti berikut ini dengan 2020 langkah ke kanan dan 2019 langkah ke atas ataupun masalah dalam bentuk umum dengan $m$ langkah ke kanan dan $n$ langkah ke atas, jelas bahwa cara memperagakan dan cara pola bilangan pada Segitiga sudah tidak dapat digunakan lagi. Masalah ini hanya dapat diselesaikan dengan menggunakan rumus kombinasi. Dua masalah ini juga merupakan dua masalah yang 
digunakan untuk memformulasikan bentuk umum korespondensi 1-1 antara himpunan banyak lintasan terpendek antara dua titik dan himpunan cara menyusun barisan huruf $K$ dan $A$.

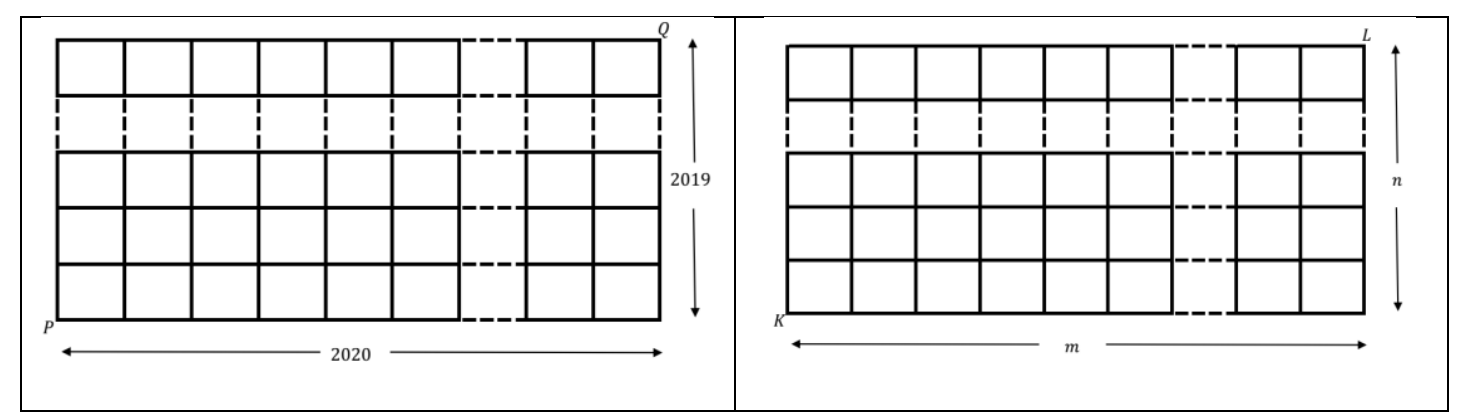

Terdapat 2020 langkah yang diperlukan untuk berjalan ke kanan dari titik $P$ menuju ke titik paling pojok bawah kanan, dan 2019 langkah yang diperlukan untuk berjalan ke atas dari titik paling pojok bawah kanan menuju ke titik $Q$. Menggunakan rumus kombinasi diperoleh banyak lintasan terpendek dari titik $P$ ke titik $Q$ adalah

$$
\left(\begin{array}{c}
2020+2019 \\
2020
\end{array}\right)=\frac{4019 !}{2020 ! \cdot 2019 !}
$$

Generalisasi dari masalah ini adalah untuk $m$ langkah yang diperlukan untuk berjalan ke kanan dari titik $K$ menuju ke titik paling pojok bawah kanan, dan $n$ langkah yang diperlukan untuk berjalan ke atas dari titik paling pojok bawah kanan menuju ke titik $L$. Diperoleh banyak lintasan terpendek dari titik $K$ ke titik $L$ adalah

$$
\left(\begin{array}{c}
m+n \\
m
\end{array}\right) \text { atau }\left(\begin{array}{c}
m+n \\
n
\end{array}\right)
$$

Penggunaan rumus kombinasi membuat masalah grid kompleks dengan bilangan besar atau bentuk umum (generalisasi) menjadi lebih cepat ditentukan solusinya.

\section{Mencacah Banyak Lintasan Terpendek Pada Grid Dengan Variasi Masalah}

Berikut ini akan disajikan variasi grid dengan terdapat kendala/hambatan pada jalurnya dan cara mencacah banyak lintasan terpendeknya. Kasus pertama adalah mencacah banyak lintasan terpendek dari titik $A$ ke titik $B$ pada grid dengan jalur dari $C$ ke $D$ tidak ada seperti di bawah ini.

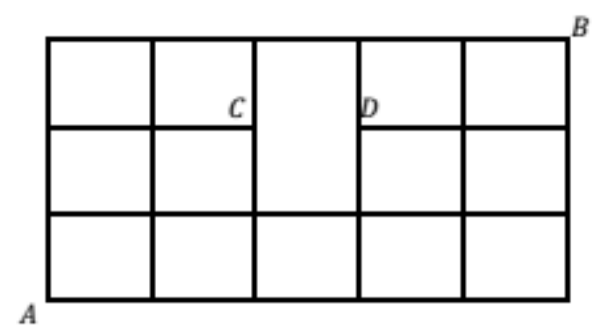

Seperti pada bagian mencacah banyak lintasan terpendek pada grid kompleks, pada masalah grid dengan kendala/hambatan ini penggunaan cara membuat gambar sudah tidak efektif dan efisien. 
Apabila menggunakan pola bilangan pada Segitiga Pascal adalah sebagai berikut.

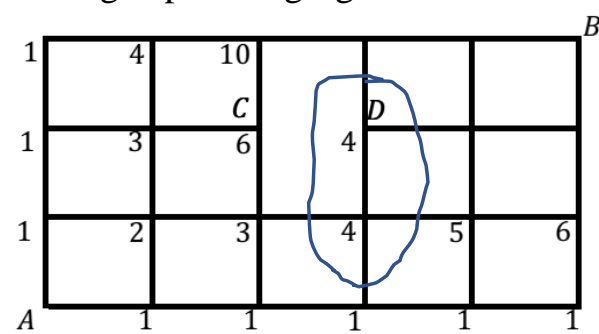

Perhatikan bahwa banyak lintasan dari $A$ sampai ke $D$ tetap 4 seperti pada titik perpotongan grid di bawahnya. Hal ini disebabkan lintasan menuju ke $D$ hanya dapat melalui titik perpotongan grid di bawahnya. Selanjutnya pencacahan banyak lintasan terpendek dilanjutkan seperti berikut.

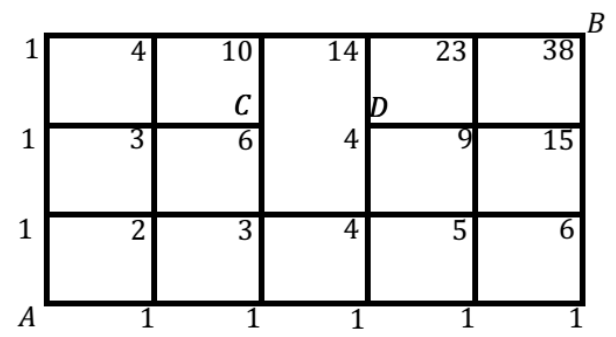

Diperoleh 38 lintasan terpendek dari $A$ ke $B$ dan tidak melalui jalur $C D$.

Apabila menggunakan rumus kombinasi adalah sebagai berikut. Perhatikan bahwa apabila terdapat jalur dari $C$ ke $D$ maka akan terdapat $\left(\begin{array}{l}8 \\ 5\end{array}\right)=56$ lintasan dari $A$ ke $B$. Karena jalur dari $C$ ke $D$ sebetulnya tidak ada maka hasil tersebut harus dikurangkan dengan lintasan dari $A$ ke $B$ dan melalui jalur $C D$. Terdapat $\left(\begin{array}{l}4 \\ 2\end{array}\right)=6$ lintasan dari $A$ ke $C, 1$ lintasan dari $C$ ke $D$, dan $\left(\begin{array}{l}3 \\ 2\end{array}\right)=3$ lintasan dari $D$ ke $B$. Menggunakan aturan perkalian diperoleh $6 \times 1 \times 3=18$ lintasan dari $A$ ke $B$ dan melalui jalur $C D$. Dengan demikian terdapat $56-18=38$ lintasan terpendek dari $A$ ke $B$ dan tidak melalui jalur $C D$.

Alternatif cara lain penggunaan rumus kombinasi adalah dengan membuat beberapa "titik simpul'. Dalam masalah ini dipilih tiga titik simpul, yaitu $E, F$, dan $G$ seperti gambar berikut ini.

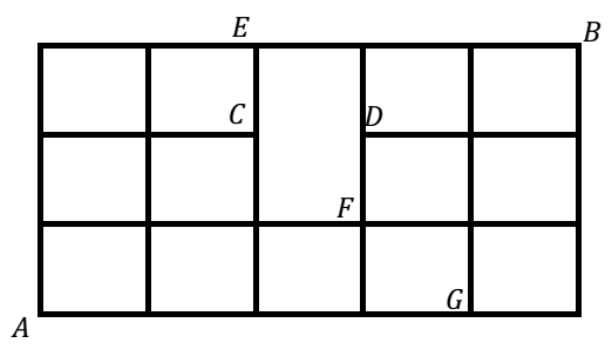

Acuan pemilihan titik simpul ini adalah titik-titik pada grid di mana lintasan yang melaluinya dapat mencakup semua lintasan dari $A$ ke $B$ dan masing-masing lintasan tersebut tidak saling beririsan (overlap). Selanjutnya mencacah banyak lintasan yang melalui masing-masing titik simpul tersebut. Pertama adalah mencacah banyak lintasan dari $A$ ke $B$ dan harus melalui $E$. 
Terdapat $\left(\begin{array}{l}5 \\ 2\end{array}\right)=10$ lintasan dari $A$ ke $E$, dan $\left(\begin{array}{l}3 \\ 3\end{array}\right)=1$ lintasan dari $E$ ke $B$. Menggunakan aturan perkalian diperoleh $\left(\begin{array}{l}5 \\ 2\end{array}\right) \cdot\left(\begin{array}{l}3 \\ 3\end{array}\right)=10$ lintasan dari $A$ ke $B$ melalui $E$. Kedua adalah mencacah banyak lintasan dari $A$ ke $B$ dan harus melalui $F$. Terdapat $\left(\begin{array}{l}4 \\ 3\end{array}\right)=4$ lintasan dari $A$ ke $F$, dan $\left(\begin{array}{l}4 \\ 2\end{array}\right)=6$ lintasan dari $F$ ke $B$. Menggunakan aturan perkalian diperoleh $\left(\begin{array}{l}4 \\ 3\end{array}\right) \cdot\left(\begin{array}{l}4 \\ 2\end{array}\right)=24$ lintasan dari $A$ ke $B$ melalui $F$. Ketiga adalah mencacah banyak lintasan dari $A$ ke $B$ dan harus melalui $G$. Terdapat $\left(\begin{array}{l}4 \\ 4\end{array}\right)=1$ lintasan dari $A$ ke $G$, dan $\left(\begin{array}{l}4 \\ 1\end{array}\right)=4$ lintasan dari $G$ ke $B$. Menggunakan aturan perkalian diperoleh $\left(\begin{array}{l}4 \\ 4\end{array}\right) \cdot\left(\begin{array}{l}4 \\ 1\end{array}\right)=4$ lintasan dari $A$ ke $B$ melalui $G$. Selanjutnya dengan menggunakan aturan penjumlahan dicacah banyak lintasan terpendek dari $A$ ke $B$ melalui masing-masing titik simpul $E, F$, dan $G$. Dengan demikian diperoleh $\left(\begin{array}{l}5 \\ 2\end{array}\right) \cdot\left(\begin{array}{l}3 \\ 3\end{array}\right)+\left(\begin{array}{l}4 \\ 3\end{array}\right) \cdot\left(\begin{array}{l}4 \\ 2\end{array}\right)+\left(\begin{array}{l}4 \\ 4\end{array}\right) \cdot\left(\begin{array}{l}4 \\ 1\end{array}\right)=10+24+4=38$ lintasan terpendek dari $A$ ke $B$.

Pencacahan menggunakan rumus kombinasi memberikan hasil yang sama dengan apabila menggunakan cara pola bilangan pada Segitiga Pascal.

Variasi grid berikutnya adalah mencacah banyak lintasan terpendek dari $A$ ke $B$ pada grid seperti berikut ini.

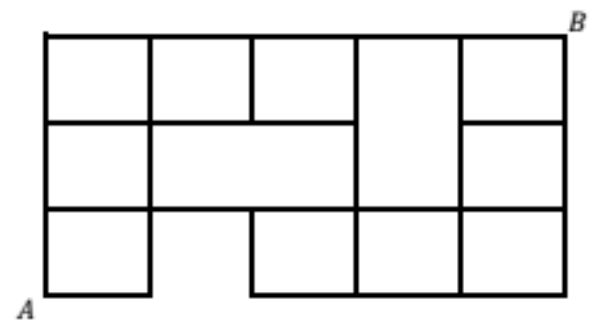

Apabila menggunakan pola bilangan pada Segitiga Pascal adalah sebagai berikut.

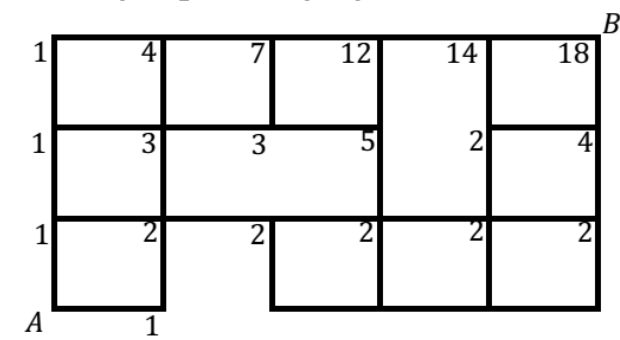

Perhatikan bahwa pada garis paling bawah tidak perlu dicacah lintasannya karena ada arah lintasan ke bawah sehingga pasti tidak mungkin yang terpendek. Sehingga terdapat 18 lintasan terpendek dari $A$ ke $B$.

Alternatif cara lain penggunaan pola bilangan pada Segitiga Pascal pada masalah ini adalah dengan mengubah sudut pandang. Gambar grid diputar sehingga menjadi berbentuk seperti ini. 


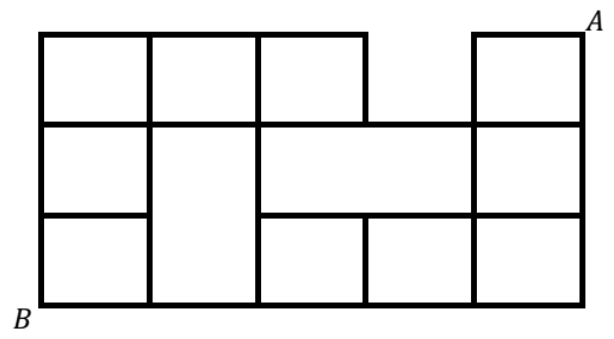

Perubahan sudut pandang ini menyebabkan pencacahan lintasan terpendek adalah dari $B$ ke $A$. Diperoleh hasil seperti berikut.

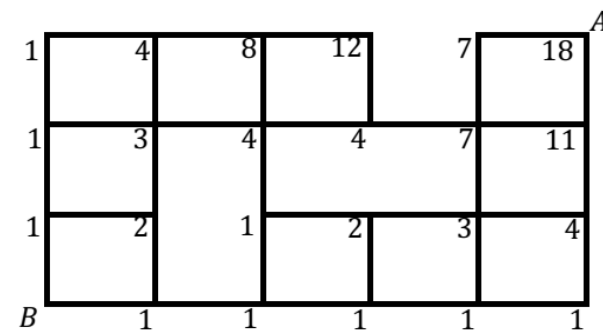

Dengan demikian diperoleh 18 terpendek dari $B$ ke $A$. Hasil ini sama dengan cara pencacahan sebelumnya.

Apabila pencacahan dilakukan dengan menggunakan rumus kombinasi melalui pemilihan titik-titik simpul justru menyebabkan tidak efektif dan efisien. Hal ini disebabkan sulitnya pemilihan titik simpul pada masalah tersebut.

Pada grid dengan variasi masalah berupa kendala/hambatan ini diperlukan kejelian dan fleksibilitas pemilihan cara pencacahan. Setiap variasi masalah yang berbeda akan menyebabkan perbedaan pemilihan cara pencacahan sehingga tidak dapat dibuat generalisasi.

\section{Implikasi Pada Cara Pembelajaran di Kelas}

Masalah mencacah banyak lintasan terpendek antara dua titik pada grid tidak termasuk dalam Kompetensi Dasar pada kurikulum matematika di sekolah. Masalah ini hanya muncul pada kelas pengayaan ataupun kelas untuk pembinaan menghadapi olimpiade matematika. Akan tetapi untuk pembelajarannya tidak boleh hanya dengan sekedar memberikan soal dan rumus saja. Guru harus memberikan kesempatan kepada siswa untuk mengonstruksi pengetahuannya sendiri. Sebagai langkah awal dalam pembelajaran harus dimulai dengan cara membuat gambar (representasi visual). Hal ini disebabkan dengan membuat gambar menjadikan solusi dari masalah secara intuitif mudah untuk dipahami siswa. Selanjutnya dengan menggunakan pola bilangan pada Segitiga Pascal. Sebagai generalisasinya siswa mengonstruksi rumus kombinasi. Penggunaan rumus kombinasi membuat masalah grid dengan bilangan besar atau bentuk umum (generalisasi) menjadi lebih cepat ditentukan solusinya. Apabila ketiga cara tersebut dapat dibelajarkan dan dikuasai, maka siswa akan mempunyai fleksibilitas dalam memecahkan masalah ketika dihadapkan dengan berbagai variasi masalah lintasan terpendek pada grid (Patrick, 2006). Fleksibilitas berpikir karena menguasai berbagai macam cara dan strategi pemecahan masalah ini sebaiknya juga dikembangkan dalam proses pembelajaran di kelas pada saat siswa mempelajari materi standar kurikulum. 


\section{Simpulan}

Setidaknya terdapat tiga cara untuk mencacah banyak lintasan terpendek antara dua titik pada grid, yaitu dengan cara membuat gambar (representasi visual), menggunakan pola bilangan pada Segitiga Pascal, dan menggunakan rumus kombinasi. Untuk grid sederhana ketiga cara dapat digunakan semua. Cara membuat gambar menjadikan langkah solusi lebih mudah dipahami. Untuk grid kompleks hanya rumus kombinasi yang dapat digunakan, atau kadangkadang cara pola bilangan pada Segitiga Pascal masih dapat digunakan. Penggunaan rumus kombinasi membuat masalah grid dengan bilangan besar atau bentuk umum (generalisasi) menjadi lebih cepat ditentukan solusinya. Untuk grid dengan variasi masalah berupa kendala/hambatan diperlukan kejelian dan fleksibilitas pemilihan cara pencacahan. Setiap variasi masalah yang berbeda akan menyebabkan perbedaan pemilihan cara pencacahan sehingga tidak dapat dibuat generalisasi.

\section{Daftar Pustaka}

Allenby, R. B. J. T. dan Alan Slomson. 2011. How to Count: An Introduction to Combinatorics. Boca Raton: FL: Taylor and Francis Group, LLC.

Beeler, Robert A. 2015. How to Count: An Introduction to Combinatorics and Its Applications. Heidelberg: Springer International Publishing.

Brualdi, Richard A. 2010. Introductory Combinatorics. Hong Kong: Pearson Education, Inc.

Chong, Chen Chuan dan Koh Khee Meng. 2010. Principles and Techniques in Combinatorics. Singapore: World Scientific Co. Pte. Ltd.

Griffiths, Martin. 2008. The Backbone of Pascal's Triangle. Leeds: The United Kingdom Mathematics Trust.

Kheyfits, Alexander. 2010. A Primer in Combinatorics. Berlin: Walter de Gruyter GmbH \& Co.

Loehr, Nicholas A. 2011. Bijective Combinatorics. Boca Raton: FL: Taylor and Francis Group, LLC.

Meng, Koh Khee dan Tay Eng Guan. 2013. Counting, Singapore: World Scientific Co. Pte. Ltd.

Musser, Gary L., Blake E. Peterson, dan William F. Burger. 2014. Mathematics for Elementary Teachers: A Contemporary Approach. Hoboken, NJ: John Wiley \& Sons, Inc.

Patrick, David. 2006. The Art of Problem Solving: Introduction to Counting and Probability, Alpine, CA: AoPS Inc.

Patrick, David. 2007. The Art of Problem Solving: Intermediate Counting and Probability, Alpine, CA: AoPS Inc.

Tucker, Alan. 2012. Applied Combinatorics. Hoboken, NJ: John Wiley \& Sons, Inc.

Wiworo. 2016. Cara Menentukan Banyak Lintasan Terpendek Antara Dua Titik Pada Suatu Grid. Artikel dimuat pada proceeding Seminar Nasional Pendidikan Matematika (Sendimat) III Tahun 2015. Yogyakarta: PPPPTK Matematika. 